\title{
IMPLEMENTASI METODE NAÏVE BAYES DALAM PERANCANGAN SISTEM PENUNJANG KEPUTUSAN PENINGKATAN POLA HIDUP SEHAT BERBASIS ANDROID
}

\author{
Hartatik,S.Si, M.Si. \\ Fakultas MIPA, Program Studi D3 Teknik Informatika \\ Universitas Sebelas Maret \\ Email: hartatik.uns@gmail.com \\ P. K. Wardhani, \\ Program Studi D3 Teknik Informatika \\ Universitas Sebelas Maret \\ Email: purivacuity@gmail.com
}

\begin{abstract}
ABSTRAK
Kesehatan merupakan kebutuhan setiap individu, namun karena kesibukan yang terlalu tinggi terkadang banyak yang belum sadar dan mengoptimalkan menjalani pola hidup yang sehat. Pola hidup sehat adalah pilihan yang terbaik yang bisa dilakukan untuk menjaga tubuh tetap sehat khususnya pengaturan keseimbangan berat badan sehingga bisa ideal. Dalam hal ini pernanan teknologi informasi sebagai sumber informasi sangatlah besar dalam mendukung pengaturan pola hidup yang sehat. Salah satunya adalah adanya sistem penunjang keputusan sebagai media komunikasi pribadi bagi setiap orang guna membantu proses pengaturan pola hidup sehat.

Perancangan Sistem yang dibangun nantinya berupa Aplikasi Mobile dan Website berbasis web yang diharapkan dapat membantu masyarakat dalam mengambil keputusan guna meningkatkan pola hidup sehat dan mendapatkan informasi tentang kesehatan maupun perawatan tubuh. Sistem ini memberikan rekomendasi tentang menu atau makanan yang cocok buat program pola hidup sehat (diet). Sistem Pendukung Keputusan ini dikembangkan dengan metode observasi, pengumpulan data, analisa data, desain dan perancangan, serta implementasi. Sistem penunjang keputusan ini menggunkaan konsep teorema bayes dan dibangun dengan dengan menggunakan bahasa pemrograman HTML, CSS, dan Java Script untuk tampilannya, dan bahasa pemrograman PHP (Hypertext Preprocessor) untuk pemrograman web.
\end{abstract}

Kata kunci: bayes, Bayesian, java, SPK, naïve bayes, diet

\section{ABSTRACT}

Health is the need of every individual, but because of too high busyness that has not been conscious and optimal to live a healthy lifestyle. Healthy lifestyle is the best choice that can be done to keep the body healthy. In this case pernanan information technology as a great source of information in support of healthy lifestyle arrangement. One of them is the expert system as a personal communication media for each person to help the process of healthy lifestyle arrangement.

The design of the system is built quickly Web and web-based web applications are expected to help people in making decisions to improve healthy lifestyle and information about health and body care. This system provides recommendations on the menu or foods that are suitable for a healthy lifestyle program (diet). This decision support system is developed by the method of observation, data completion, data analysis, design and design. This decision support system uses the Bayes theorem concept and is built using HTML, CSS, and Java Script programming languages for features, and the PHP programming language (Hypertext Preprocessor) for web programming.

Keywords: bayes, Bayesian, java, SPK, naïve bayes, diet 


\section{PENDAhULUAN}

Pada umunya masyarakat Indonesia memiliki jiwa yang produktif, memiliki kegiatan yang padat setiap harinya namun tidak terlalu memperhatikan pola makan dan kesehatan tubuhnya. Kurangnya olahraga dan ditambah lagi dengan kemudahan mendapatkan makanan dari lingkungan sekitar yang lebih banyak memiliki resto atau rumah makan yang menjual makanan yang tidak sehat untuk tubuh, membuat mudahnya masyarakat Indonesia tidak mematuhi aturan pola hidup sehat. . Kesibukan yang dihadapi oleh setiap orang menyebabkan mereka mengabaikan pola hidup mereka sehingga bisa menyebabkan lupa makan yang mengakibatkan kekurangan asupan gizi maupun bisa meneyebabkan obesitas. Sehingga muncul sekarang banyak metode untuk menurunkan berat badan (diet).

Diet merupakan sebuah usaha untuk mengurangi atau mengontrol asupan makanan yang bertujuan untuk mengurangi atau mempertahankan berat badan sesuai dengan keinginan individu [1]. Diet merupakan salah satu cara yang populer untuk menurunkan berat badan. Diet dapat dilakukan dengan cara yang benar dan sehat, namun juga tidak jarang yang melakukannya dengan cara yang tidak sehat. Diet yang sehat adalah dengan mengkonsumsi makanan yang sehat dan menambah aktifitas fisik secara wajar. Sedangkan diet yang tidak sehat adalah diet yang dilakukan lewat beberapa cara yaitu: dengan sengaja melewatkan waktu makan, minum obat pelangsing, dan muntah dengan sengaja [2].

Dengan melihat permasalahan tersebut, maka setiap individu yang ingin merubah pola hidupnya menjadi lebih baik dan ingin terhindar dari Obesitas memerlukan sebuah alat bantu yang dapat membantu permasalahan mereka untuk mengatur pola hidup yang sehat secara cepat dan terstrukstur. Oleh karena itu perlu dibangunnya suatu aplikasi yang membantu pola hidup sehat yang sesuai dengan kebutuhan yang disesuaikan dengan berat dan tinggi badan setiap individu masing-masing. Sehingga masyarakat memiliki kemudahan dalam mengatur pola hidup yang sesuai dengan kebutuhannya.

Disamping itu dengan adanya perkembangan teknologi, telah banyak ditemukan alat bantu yang digunakan untuk membantu memperlancar pekerjaan. Salah satunya adalah system kecerdasan buatan atau system pakar, yaitu implementasi dari sistem yang bisa dikembangkan dari salah satu keahlian tertentu dengan menggunakan komputer. Sistem Pendukung Keputusan (SPK) atau Decission Support System (DSS) merupakan sistem informasi interaktif yang menyediakan informasi, pemodelan dan manipulasi data. Sistem itu digunakan untuk membantu pengambilan keputusan dalam situasi yang semi terstruktur dan situasi yang tidak terstruktur, dimana tidak ada seorang pun tahu pasti bagaimana keputusan seharusnya dibuat. SPK biasanya dibangun untuk mendukung solusi atas suatu masalah atau untuk mengevaluasi suatu peluang yang ada [3].

Senada dengan para pakar lainnya, Raymond [4]. Dalam bukunya Sistem Informasi Manajemen menekankan bahwa "Sistem Pendukung Keputusan adalah suatu sistem informasi yang ditujukan untuk membantu manajemen dalam memecahkan masalah yang dihadapinya.". Oleh karena itu berdasarkan uraian tersebut, menarik untuk mengembangkan alat bantu berupa suatu website dan aplikasi android yang mampu membantu pengguna managemen pola hidup sehat dan mengontrol berat badan sehingga tidak terjadi obesitas ataupun berat badan yang jauh dari berat badan ideal, serta bisa membantu memberikan informasi tentang rekomendasi menu yang sesuai dengan kebutuhan diet pengguna.

Penelitian sejenis sebelumnya tentang konsultasi menu diet bagi Penderita diabetes mellitus berbasis aturan [5], yang selanjutnya pada penelitian ini akan dikembangkan untuk sistem penunjang keputusan berbasis web dan android guna penentuan menu diet dan monitoring diet sebagai wujud peningkatan pola hidup sehat. 


\section{METODOLOGI PENELITIAN}

Sistem Pendukung Keputusan merupakan suatu sistem interaktif yang mendukung keputusan dalam proses pengambilan keputusan melalui alternatif-alternatif yang diperoleh dari hasil pengolahan data, informasi dan rancangan model [6]. Penelitian ini mengacu kepada subsistem di dalam system pendukung keputusan yaitu :

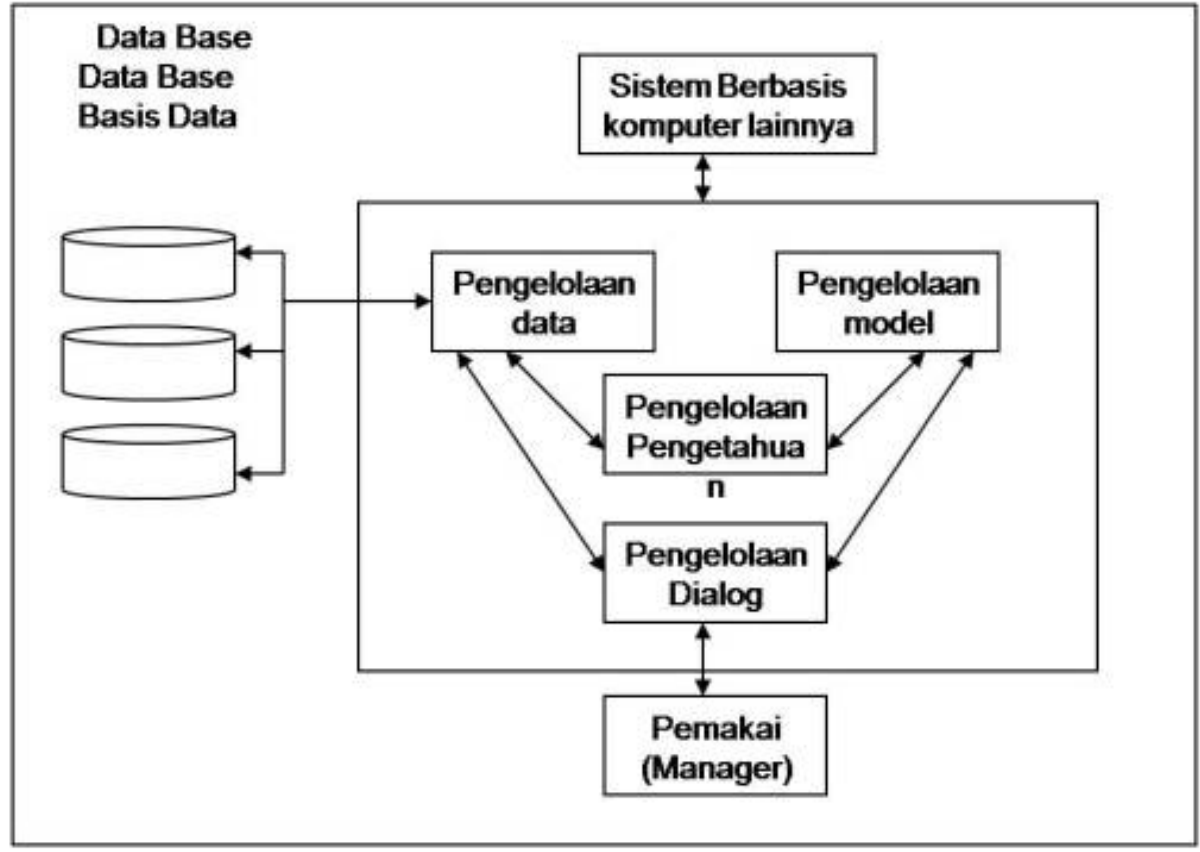

Gambar 1. Susbsistem dalam SPK berikut :

Berdasarkan subsistem SPK pada gambar 1, langkah langkah dalam penelitian ini adalah sebagai

a. Pengumpulan Data

Pada metode pengumpulan data ini penulis melakukan studi lapangan yang terdiri dari observasi dan wawancara. Observasi dan wawancara dilakukan pada wanita usia produktif, remaja dan dewasa (usia 1845 tahun) serta di Resto-resto sekitar Kota Surakarta untuk mengumpulkan data mengenai kuliner atau menu sehat yang mereka hidangkan. Penulis juga mempelajari melalui artikel maupun buku untuk mengumpulkan data mengenai cara-cara menjaga pola hidup sehat dan menghindari obesitas, serta mengumpulkan informasi mengenai kandungan gizi pada setiap makanan.

\section{b. Analisa Data}

Melakukan analisa terhadap data-data yang diperoleh dari hasil pengumpulan data yaitu dengan deskriptive yaitu survey terhadap perilaku diet pada masyakat . Survey ini digunakan untuk menunjang pernacangan sistem penunjang keputusan yang berupawebsite dan Aplikasi Mobile. Pada metode analisa data ini penulis juga menganalisa proses bisnis sebagai inti dari permasalahan yang dijadikan sebagai bahan dan acuan pembuatan Website dan Aplikasi Mobile.

Dalam proses analisa data ini termasuk langkah pengelolaan model dan pengetahuan di dalam subsistem SPK dipersiapkan konsep dan teori tentang sistem penunjang keputusan yaitu dengan naive bayes serta penjelasan tentang penentuan type pola hidup sehat.

c. Desain dan Perancangan 
Setelah data dianalisa dan telah mendapatkan ide dan konsep dasar sistem, maka tahapan yang dilakukan selanjutnya adalah membuat desain guna komunikasi, yang terdiri dari tiga jenis yaitu desain proses sistem, desain database dan desain user interface untuk pengembangan sitem Pendukung keputusan menggunakan metode bayesian.

d. Desain Proses Sistem

Desain proses sistem merupakan desain atau perancangan terhadap alur dan logika sistem. Pada desain proses sistem, disusun alur proses sistem dalam bentuk class diagram karena sistem akan dikembangkan dengan menggunakan framework yang menggunakan OOP (Object Oriented Programming).

\section{e. Desain Model Database}

Desain database merupakan desain dari sebuah tempat penyimpanan data pada sebuah Aplikasi Mobile dan Website. Desain database disusun dalam bentuk ERD (Entity Relationship Diagram). ERD merupakan hubungan dari entitas-entitas data yang memiliki atribut-atribut yang akan diwujudkan dalam bentuk tabel-tabel penyimpan data.

\section{f. Desain User Interface}

Desain user interface merupakan rancangan tampilan antarmuka dari Aplikasi Mobile dan Website yang menggambarkan tata letak (layout) komponen-komponen yang dibutuhkan pada Aplikasi Mobile dan Website yang akan dibuat. Rancangan antarmuka ini dibuat semenarik mungkin namun tidak melupakan unsur kemudahan user dalam menjalankan Aplikasi Mobile dan Website. Desain user interface digunakan untuk dasar membuat tampilan Aplikasi Mobile dan Website yang nantinya akan digunakan oleh user.

\section{HASIL DAN PEMBAHASAN}

Berdasarkan hasil survey dari 60 responden yang terdiri dari user (pria dan wanita usia di atas 17 tahun) didapatkan bahwa untuk management pola hidup sehat , dalam hal ini untuk mencapai berat badan ideal dengan cara diet atau program penggemukan didapatkan bahwa untuk remaja (usia kurang dari 20 tahun) sebagian besar tidak mengalami permasalahan dalam berat badan ideal , terlihat dari responden $10 \%$ yang melakukan program diet $10 \%$ melakukan program penggemukan, selebihnya tidak. Hal ini juga terlihat bahwa masalah berat badan ideal dihadapi oleh mayoritas wanita usia di atas 30 tahun. Terbukti dengan pada responden dengan usia di atas 30 tahun, 70\% menyatakan melakukan program diet, 20\% melakukan program penggemukan, selebihnya tidak mengalami masalah berat badan.

Berdasarkan hasil pengolahan dan analisa data tersebut, dibuat aplikasi yang memudahkan bagi pengguna untuk melakukan management pola hidup sehat. Aplikasi system penunjang keputusan berbasis android ini dirancang untuk bisa membantu dalam hal management pola hidup sehat, khuususnya menyeimbangkan berat badan, yang lebih khusus lagi bagi para wanita. Aplikasi Android diawali dengan user yang melakukan registrasi atau pendaftaran terlebih dahulu pada aplikasi, menginputkan data diri yang dibutuhkan dalam menjalankan aplikasi, yaitu berupa nama, email, password, berat badan, tinggi badan, usia, dan jenis kelamin. Setelah data diterima oleh system, data akan disimpan dalam database aplikasi dan system mulai mengolah data, menghitung berat badan ideal yang seharusnya dimiliki oleh user. Bila berdasarkan analisa system dalam aplikasi menyatakan bahwa berat badan ideal user kurang dari berat user, maka user akan langsung diarahkan menuju metode pengurusan badan, dan system akan memberikan output berupa metode yang dapat diikuti user yang direkomendasikan oleh system berdasarkan data user (usia dan jenis kelamin) tersebut. Namun jika sebaliknya maka akan diarahkan menuju metode penggemukan badan.

Sistem pendukung keputusan ini dilengkapi dengan pilihan metode yang cocok bagi user. Untuk proses pengurusan badan, system Pendukung Keputusan Diet ini mengkategorikan keadaan sekarang users dalam suatu tingkat diet sesuai dengan keadaan sekarang. Selanjutnya adalah penjadwalan dan penyusunann menu makanan, setelah user memilih menu makanan yang direkomendasikan, sistem mulai mengatur penjadwalan berdasarkan menu makanan yang dipilih user tersebut. Sistem juga menyiapkan 
reminder atau pengingat untuk memudahkan penjadwalan user. Demikian halnya untuk proses penggemukan.

\section{3a. Metode Bayesian guna klasifikasi kategori Diet}

Langkah penentuan type diet dikenalkan oleh [7] yaitu dengan metode aturan RSCM yaitu dengan menentukan kebutuhan kalori users, dimana type diet dapat ditentukan dari persamaan berikut:

$B B I=90 \% x(T B-100)$

Kalori Awal (KA) $=\frac{\text { BBI }}{B B A} *$ KaloriJK (4).

Kalori Total $=\mathbf{K A}-(\mathbf{K A} * \% \mathbf{u m u r})+(\mathbf{K A} * \%$ aktifitas $)-/+(\mathbf{K A} * \% \mathbf{B B})$

Kalori Awal adalah kalori yang dihasilkan dari perkalian BBI atau BBA dengan jenis kelamin. Untuk jenis kelamin laki-laki maka dikalikan 30 kkal sedangkan untuk jenis kelamin perempuan dikalikan $25 \mathrm{kkal}$. Kalori ini dijadikan acuan untuk mendapatkan kalori tambahan lain dari faktorfaktor pendukung lainnya. Perhitungan tambahan faktor-faktor yang menentukan kebutuhan kalori antara lain [7] :

a. Jenis kelamin

Kebutuhan kalori (bobot) pada wanita lebih kecil dibandingkan pria. Kebutuhan kalori wanita sebesar $25 \mathrm{kal} / \mathrm{kg}$ BB dan pria sebesar $30 \mathrm{kal} / \mathrm{kg} \mathrm{BB}$.

b. Umur

Untuk pasien usia diatas 40-59 tahun kebutuhan kalori (bobot) dikurangi $5 \%$, untuk usia diantara 60-69 tahun dikurangi $10 \%$ dan untuk usia diatas 69 tahun dikurangi $20 \%$.

c. Aktifitas fisik

Penambahan $10 \%$ dari kebutuhan kalori (bobot) diberikan pada keadaan istirahat, $20 \%$ pada pasien dengan aktifitas ringan, $30 \%$ dengan aktifitas sedang dan $50 \%$ dengan aktifitas berat. Klasifikasi jenis aktifitas dan contoh kegiatan dapat dilihat dalam Tabel 1.

d. Jenis Berat badan

Bila gemuk, dikurangi $25 \%$ bergantung pada tingkat kegemukan, dan bila kurus ditambah $25 \%$ sesuai kebutuhan untuk meningkatkan berat badan, bila ideal maka bisa diabaikan.

Tabel 1. Tabek aktifitas kegiatan fisik

\begin{tabular}{|l|l|}
\hline Aktifitas & Contoh \\
\hline IStirahat & $\begin{array}{l}\text { Tidur, Duduk, tidak bekerja, } \\
\text { menganggur }\end{array}$ \\
\hline Ringan & $\begin{array}{l}\text { Asisten RT, menjahit, Mencuci, } \\
\text { menyetrika }\end{array}$ \\
\hline Sedang & $\begin{array}{l}\text { Bekerja, PNS, peg swasta, } \\
\text { Petani, nelayan, parttime, dosen }\end{array}$ \\
\hline Berat & $\begin{array}{l}\text { Kuli bangunan, tukang kayu, } \\
\text { penarik becak, tukang pasar }\end{array}$ \\
\hline
\end{tabular}

Sedangkan kategori diet menurut [7], seperti tertera dalam table 2 berikut: 
Tabel 2. Tabek kesamaan diet kalori

\begin{tabular}{|c|c|c|}
\hline Jenis Diet & $\begin{array}{l}\text { Energi } \\
\text { (kkal) }\end{array}$ & $\begin{array}{l}\text { Energi versi RSUD } \\
\text { (kkal) }\end{array}$ \\
\hline I & $<1200$ & 1100 \\
\hline II & $1201-1400$ & 1300 \\
\hline III & $1401-1600$ & 1500 \\
\hline IV & $1601-1800$ & 1700 \\
\hline V & $1801-2000$ & 1900 \\
\hline VI & $2001-2200$ & 2100 \\
\hline VII & $2201-2400$ & 2300 \\
\hline VIII & $>2401$ & 2500 \\
\hline
\end{tabular}

Lebih detailnya, sebagai illustrasi perhitungan sesuai aturan RSCM penentuan kategori pola hidup sehat, misalkan berat badan $85 \mathrm{~kg}$, tiggi badan $175 \mathrm{~cm}$ sebagai berikut:

1. Langkah pertama menentukan indeks massa tubuh (IMT) dengan rumus BB kg / (TB) ${ }^{2} \mathrm{~m}$ $=85 / 3,0625=27,75$.

2. Langkah kedua adalah mengklasifikasikan hasil IMT sehingga pasien dikategorikan memiliki BB lebih menggunakan BB Ideal karena 27,75 termasuk dalam BB lebih.

3. Langkah ketiga adalah mencari kalori awal (KA) yaitu Berat Badan ideal dikalikan dengan prosentasi jenis kelamin yaitu $67,5 * 30=2025$.

4. Langkah keempat adalah prosentase umur dikalikan kalori awal. Umur yang dipilih adalah diatas 69 tahun sehingga prosentasenya 20\% sehingga 20\%*2025 $=405$.

5. Langkah kelima adalah prosentase aktifitas dikalikan KA yaitu $20 \% * 2025=405$.

6. Langkah keenam adalah prosentasi berat badan dikalikan KA yaitu $20 \% * 2025=405$. Sehubungan dengan berat badan lebih maka point nomor 6 ini akan menjadi negatif. Sebaliknya jika kondisi berat badan kurang maka nilai pada point nomor 6 ini bernilai positif.

7. Langkah terakhir adalah penentuan jumlah kalori yang dibutuhkan dengan cara point nomor (3)-(4)+(5)-(6) $=2025-405+405-405=1620$.

Dari hasil perhitungan matematis diatas dapat disimpulkan bahwa dengan beberapa input data antropometri seorang pasien didapat besar kalori adalah 1620 sehingga dengan besar kalori tersebut pasien diklasifikasikan kedalam jenis golongan diet 4.

Selanjutnya dalam penelitian ini akan digunakan metode bayes sebagai metode guna pemecahan masalah di dalam system pendukung keputusan terkait pola hidup sehat. Dalam proses perunutan maju (forward chaining) dari mesin inferensi guna penentuan kategori pola hidup sehat yang sesuai sangat dimungkinkan hasil akhir diagnosa ada beberapa kategori yang terpilih. Untuk memilih satu dari beberapa kategori yang terpilih memerlukan manajemen ketidakpastian[8]. Ketidakpastian ini akan dihitung menggunakan teorema probabilitas bayes, dengan

$$
P(H \mid X)=\frac{P(X \mid H) P(H)}{P(X)}
$$

Dalam konteks prediksi diet yang sesuai berdasarkan berat badan dan tinggi badan, berdasarkan rumus Naïve Bayes diatas, maka $\mathrm{H}$ merepresentasikan type diet seseorang. $\mathrm{P}(\mathrm{H})$ adalah prior probability dimana kasus ini merupakan probabilitas seseorang masuk dalam kategori 
diet tertentu. $\mathrm{P}(\mathrm{H} \mid \mathrm{X})$ merefleksikan probabilitas seseorang dengan $\mathrm{X}$ berupa banyaknya kalori yang dibutuhkan. $\mathrm{P}(\mathrm{X} \mid \mathrm{H})$ adalah posterior probability yang menunjukkan banyaknya kalori yang dibutuhkan berdasarkan prediktor $\mathrm{H}$. $\mathrm{P}(\mathrm{X})$ merupakan prior probability yang merupakan probabilitas seseorang dengan kriteria $\mathrm{X}$.

Berikut langkah penyelesaian dengan diagram naïve Bayes:

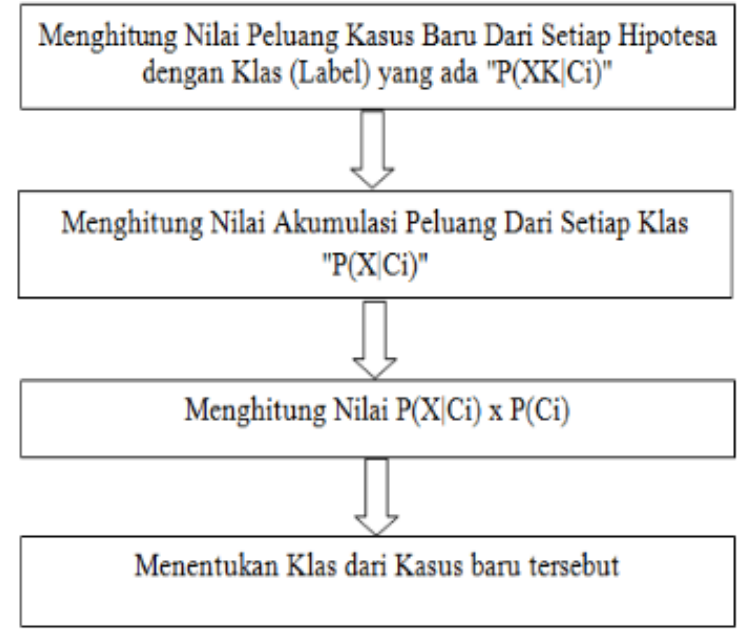

Gambar 2.Diagram penyelesaian dengan naïve bayes

Berikut simulasi perhitungan dengan metode naïve bayes dan juga aturan menu makanan sehat sesuai dengan kaegori diet.

Tabel3. Penentuan type diet dengan naïve bayesian

\begin{tabular}{|l|l|l|l|l|l|l|}
\hline & BB & TB & Umur & Aktivitas Fisik & Type Diet & \\
\hline 1 & 35 & 160 & 16 & Rendah & Diet Type II & \\
\hline 2 & 43 & 155 & 17 & Sedang & Diet Type III & \\
\hline 3 & 56 & 155 & 25 & Tinggi & & \\
\hline 4 & 67 & 160 & 29 & Rendah & & \\
\hline 5 & 78 & 155 & 35 & Sedang & & \\
\hline 6 & 75 & 160 & 38 & Tinggi & & \\
\hline 7 & 60 & 164 & 45 & Rendah & & \\
\hline 8 & 65 & 154 & 58 & Sedang & & \\
\hline & & & & & & \\
\hline
\end{tabular}

Selanjutnya nanti diarahkan bahan makanan apa yang bisa dipilih untuk menu sesuai dengan kategori diet: 
Tabel4. Menu makanana sehat

\begin{tabular}{|c|c|c|c|c|c|c|c|c|}
\hline Energi(kkal) & I & II & III & IV & $\mathbf{V}$ & VI & VII & VIII \\
\hline \multicolumn{9}{|c|}{ Pagi (Pukul 06.00 - 07.00) } \\
\hline H. Arang & $1 / 2$ & 1 & 1 & 1 & 1.5 & 1.5 & 1.5 & 2 \\
\hline Hewani & 1 & 1 & 1 & 1 & 1 & 1 & 1 & 1 \\
\hline Nabati & - & - & $1 / 2$ & $1 / 2$ & $1 / 2$ & $1 / 2$ & $1 / 2$ & $1 / 2$ \\
\hline Sayuran & $\mathrm{S}$ & $\mathrm{S}$ & $\mathrm{S}$ & $\mathrm{S}$ & $\mathrm{S}$ & $\mathrm{S}$ & $\mathrm{S}$ & $\mathrm{S}$ \\
\hline Minyak & 1 & 1 & 1 & 1 & 2 & 2 & 2 & 2 \\
\hline \multicolumn{9}{|c|}{ Pukul 10.00 } \\
\hline Buah & 1 & 1 & 1 & 1 & 1 & 1 & 1 & 1 \\
\hline Susu & - & - & - & - & - & - & 1 & 1 \\
\hline \multicolumn{9}{|c|}{ Siang (Pukul 12.00 - 13.00) } \\
\hline H. Arang & 1 & 1 & 2 & 2 & 2 & 2.5 & 3 & 2 \\
\hline Hewani & 1 & 1 & 1 & 1 & 1 & 1 & 1 & 1 \\
\hline Nabati & 1 & 1 & 1 & 1 & 1 & 1 & 1 & 2 \\
\hline Sayuran A & $\mathrm{S}$ & $\mathrm{S}$ & $\mathrm{S}$ & $\mathrm{S}$ & $\mathrm{S}$ & $\mathrm{S}$ & $\mathrm{S}$ & $\mathrm{S}$ \\
\hline Sayuran B & 1 & 1 & 1 & 1 & 1 & 1 & 1 & 1 \\
\hline Minyak & 1 & 1 & 1 & 1 & 2 & 2 & 2 & 2 \\
\hline Buah & 1 & 1 & 1 & 1 & 1 & 1 & 1 & 1 \\
\hline Susu & 1 & 2 & 2 & 2 & 2 & 3 & 3 & 3 \\
\hline \multicolumn{9}{|c|}{ Pukul 16.00 } \\
\hline Buah & 1 & 1 & 1 & 1 & 1 & 1 & 1 & 1 \\
\hline \multicolumn{9}{|c|}{ Malam (Pukul 18.00 - 19.00) } \\
\hline H. Arang & 1 & 1 & 1 & 2 & 2 & 2 & 2.5 & 2.5 \\
\hline Hewani & 1 & 1 & 1 & 1 & 1 & 1 & 1 & 2 \\
\hline Nabati & 1 & 1 & 1 & 1 & 1 & 1 & 1 & 1 \\
\hline Sayuran A & $S$ & $S$ & $S$ & $S$ & $S$ & $S$ & $S$ & $S$ \\
\hline Sayuran B & 1 & 1 & 1 & 1 & 1 & 1 & 1 & 1 \\
\hline Minyak & 1 & 1 & 1 & 1 & 2 & 2 & 2 & 2 \\
\hline Buah & 1 & 1 & 1 & 1 & 1 & 1 & 1 & 1 \\
\hline
\end{tabular}

\section{3b. Perancangan Database Sistem Penunjang Keputusan Pola Hidup Sehat}

Pernacangan system penunjang keputusan ini meliputi perancangan database terkait dengan pola pengaturan makanan guna menunjang hidup sehat. Perncangan untuk sistem ini bisa dilihat pada gambar 3dan gambar 4 berikut.

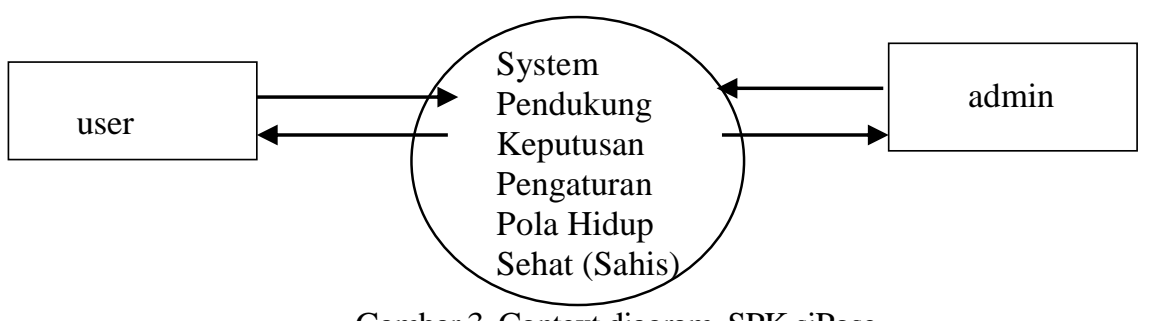

Gambar 3. Context diagram SPK siPose 
Level pengguna untuk sistem ini adalah admin dan pengguna(users) yang telah terdaftar sebagai anggota maupun yang belum terdaftar, lebih detail sebagai berikut:

1. Admin merupakan tingkatan tertinggi dalam level pengguna sistem. Fasilitas yang dimiliki adalah dapat mengakses halaman admin dan halaman database admin . Bertugas mengatur data admin dan memberikan hak akses users, dalam hal ini admin bertugas untuk mengaktifkan atau menon-aktifkan users. Tugas berikutnya dari administrator adalah mengawasi jalannya system baik websites maupun android melalui laporan laporan yang ada pada halaman database admin.

2. users yaitu Anggota dan non anggota. anggota adalah pengguna yang terdaftar sebagai anggota memiliki fasilitas untuk melakukan pengaturan pola hidup sehat dan membaca profil lengkap tentang diet. Anggota juga memiliki fasilitas pantauan diet yang dapat diisi secara berlaka untuk memantau perkembangan diet yang dijalani. Pantauan diet dapat ditampilkan berupa laporan dan grafik.

Sedangkan Pengguna yang belum terdaftar sebagai anggota, yang dapat diakses hanyalah halaman beranda yang berisi artikel kesehatan, about, dan halaman hubungi kami.

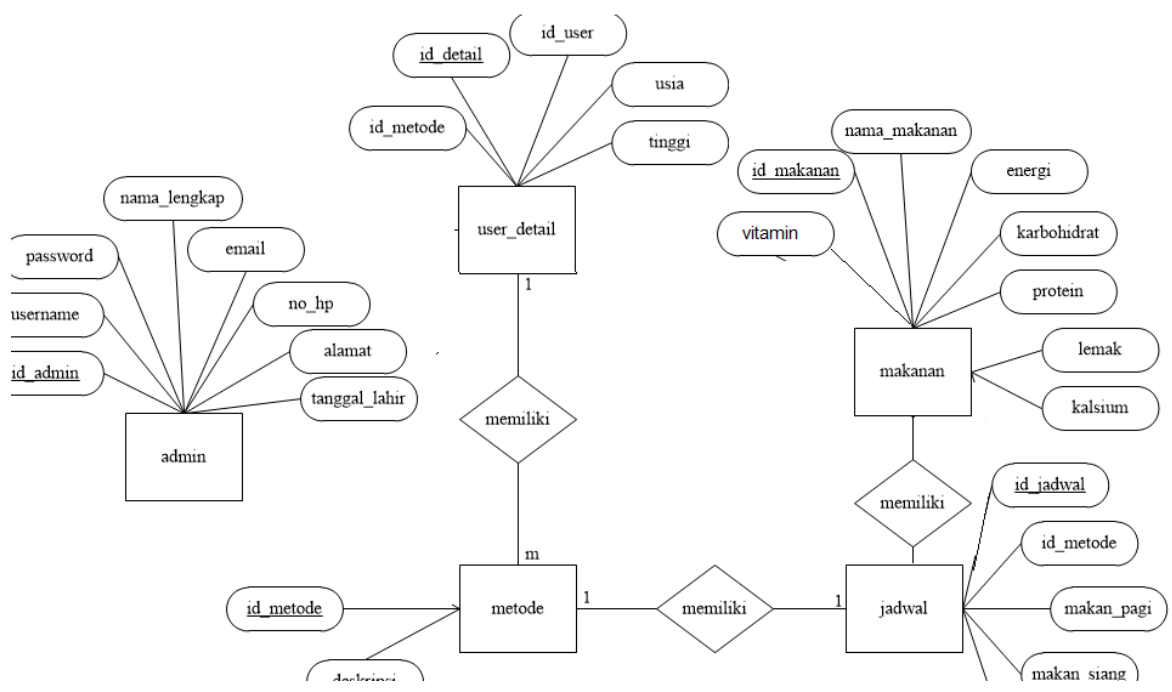

Gambar 4. ERD Aplikasi Mobile dan Website SPK system Pola Hidup Sehat 


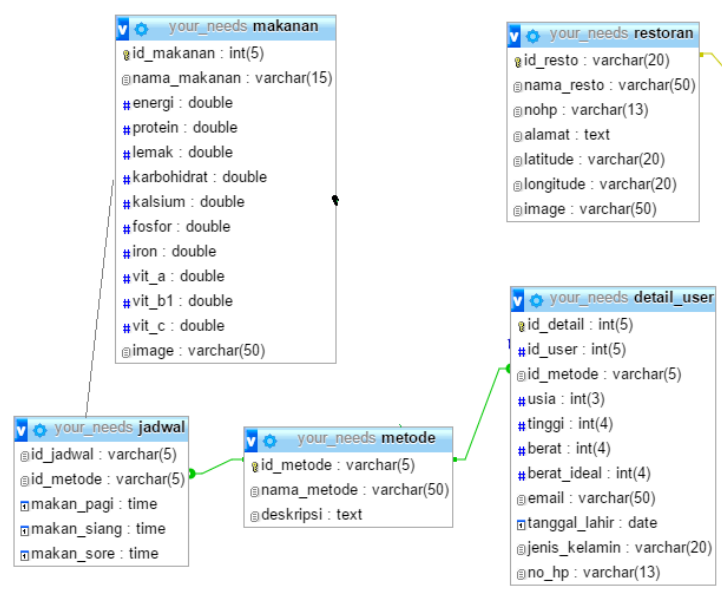

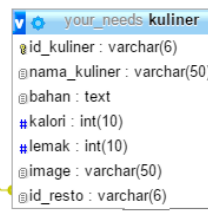

Gid_resto : varchar(6)

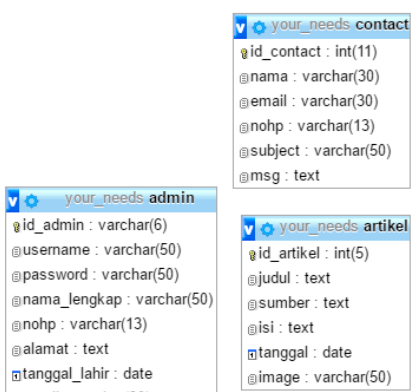

Gambar 5. Relasi Antar Tabel Aplikasi Mobile dan Website SiPose

\section{3c. Perancangan Halaman Muka Sistem Penunjang Keputusan Pola Hidup Sehat}

Halaman muka dari Sistem penunjang keputusan SiPose ini dikelompokkan dalam 2 kategori yaitu admin dan user. Admin mempunyai hak akses mengatur atas hak ases user. Ketika tab Administrator di klik maka akan redirect ke admin.php. Pada halaman ini terdapat data semua admin yang ada dengan field username dan password. Terdapat fungsi add, edit, detail, dan hapus data admin.

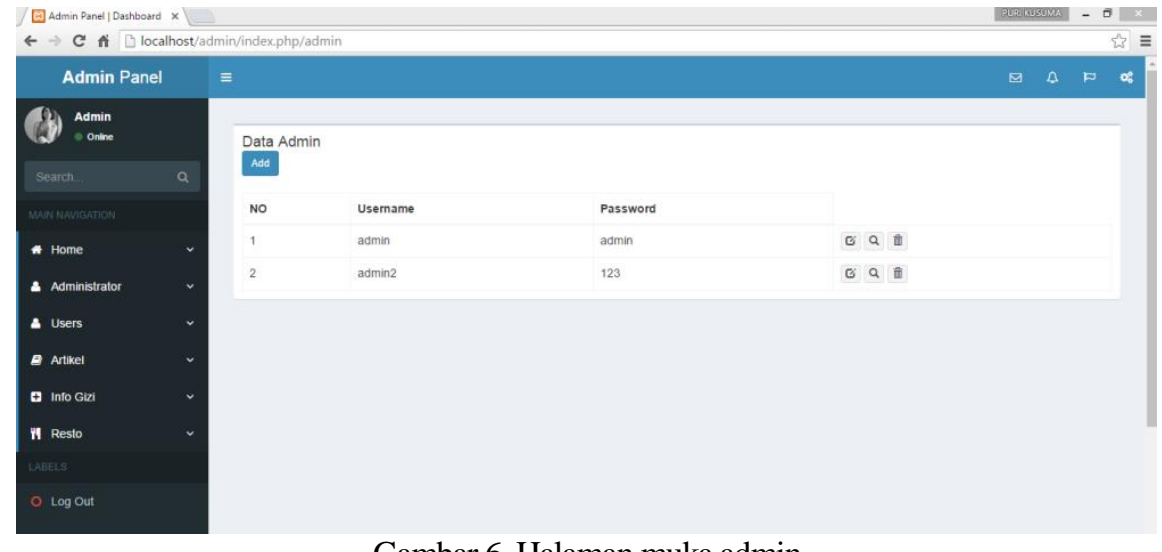

Gambar 6. Halaman muka admin

Selanjutnya Pada halaman info gizi, akan menampilkan data-data tentang info gizi pada makanan yang dikandung dalam suatu bahan makanan. Untuk menampilkan data secara lengkap juga dapat menggunakan fitur Detail, Add untuk menambahkan data, dan Delete untuk menghapus data. 


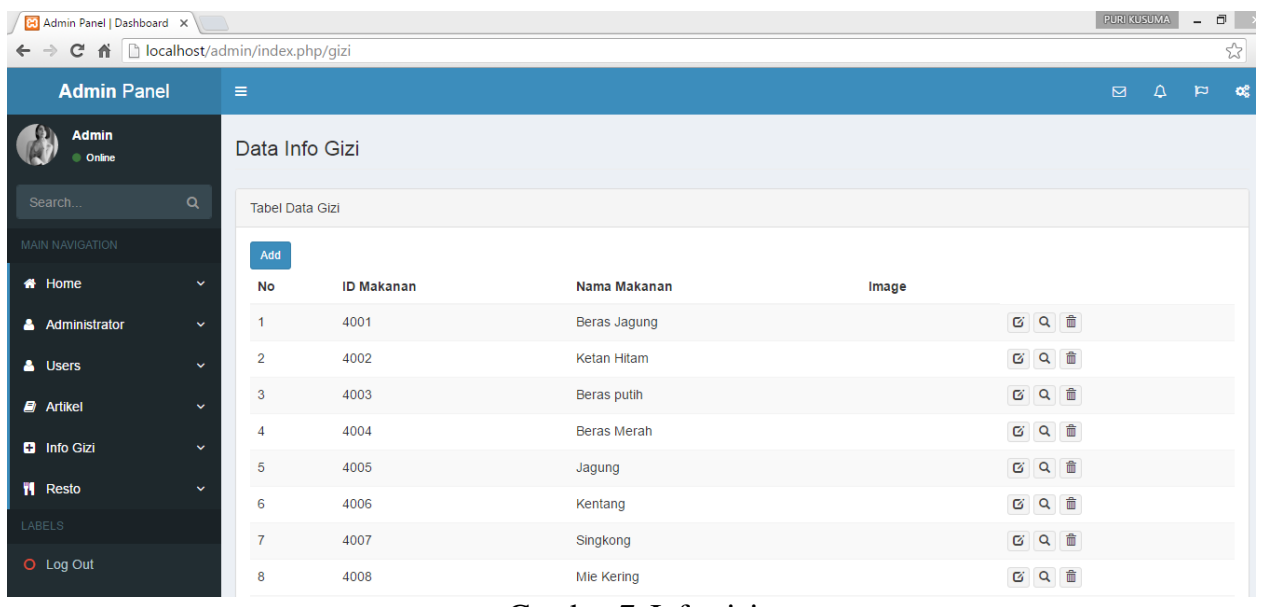

Gambar 7. Info gizi

Pada halaman Resto ini berisi data-data rekomendasi Restoran sehat yang ada Solo dan sekitrarnya. Field yang ditampilkan hanya ID Resto dan nama resto. Untuk mengetahui info lengkapnya dapat menggunakan fitur Detail pada kolom Action.

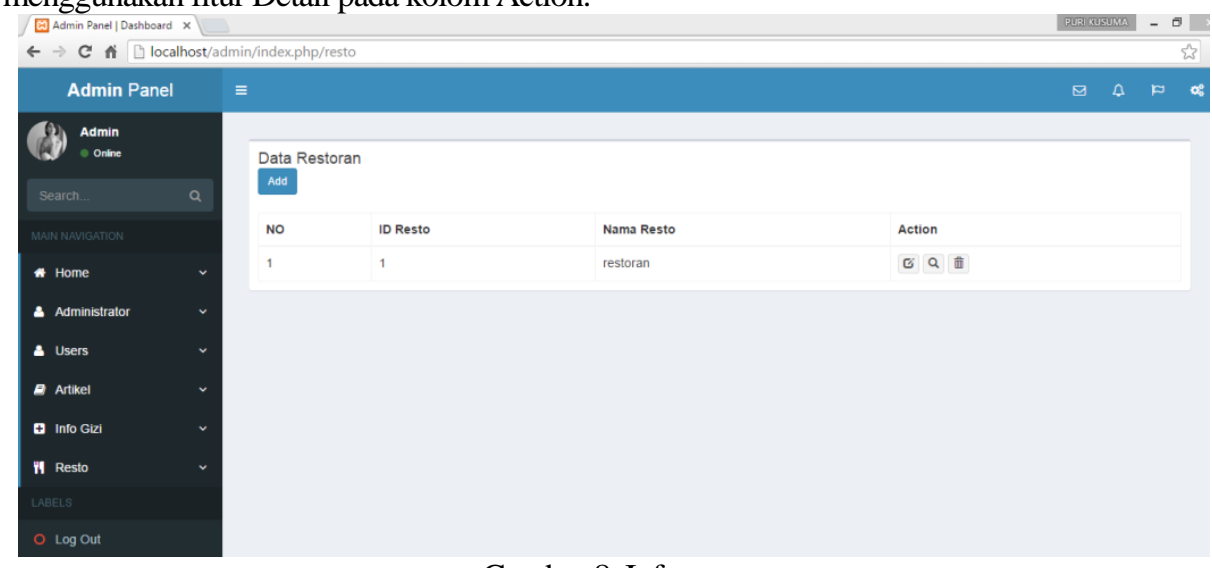

Gambar 8. Info resto

Apabila user ingin menggunakan aplikasi ini harus login terlebih dahulu. Halaman login bisa terlihat seperti pada gambar 9, selanjutnya apabila belum punya user password maka silahkan untuk register terlebih dahulu seperti pada botton sign up. 


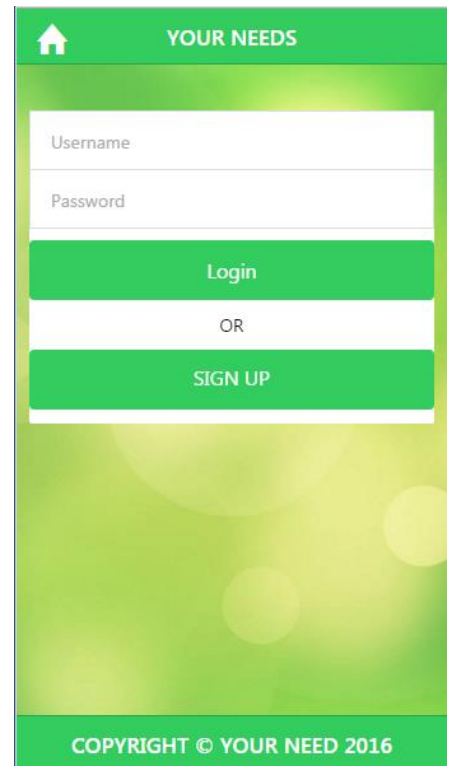

Gambar 9. Implemetasi Halaman "Sign In"

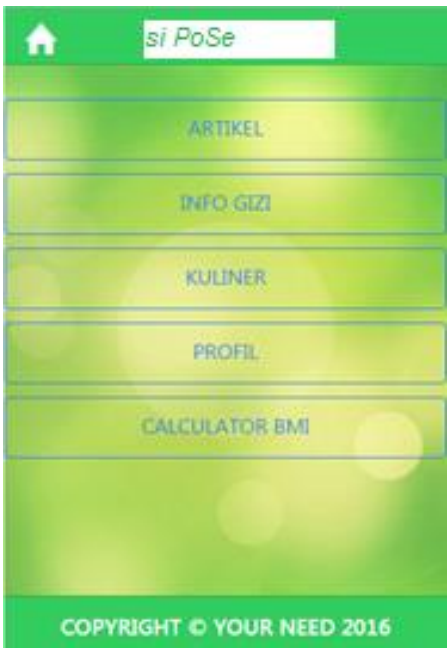

Gambar 10. Implemetasi Halaman "Home”

Setelah user masuk ke halaman utama, maka user bisa memilih fitur mana yang diinginkan. Untuk melakukan pemilihan proses peningkatan pola hidup sehat ( diet atau pengurusan ) maka users klik Calculator BMI . Maka selanjutnya user akan diminta mengisi data pribadi, seperti terlihat pafa gambar 10, dimana data pribadi ini nanatinya digunakan untuk menganalisis dengan metode Bayesian, termasuk kategori diet yang mana.

\begin{tabular}{|l|}
\hline Calculator BMI \\
\hline Your Weight $(\mathrm{Kg})$ : \\
\hline Your Height $(\mathrm{Cm})$ : \\
\hline Calculate BMI \\
\hline Your BMI : \\
\hline This Means : \\
\hline Reset \\
\hline
\end{tabular}

\section{Copyright (c) Your Need 2016}

Gambar 11. Implemetasi Halaman "BMI Calculator"

Hasil kalkultor BMI selanjutnya akan dicocokkan dengan prosedur diet dan profil genetika untuk mengetahui proses metabolisme, bahan - bahan makanan, serta supplemen yang boleh dikonsumsi oleh pengguna serta menampilkan kegiatan penunjang yang dapat membantu users dalam membakar kalori seperti terlihat gambar 12 . 


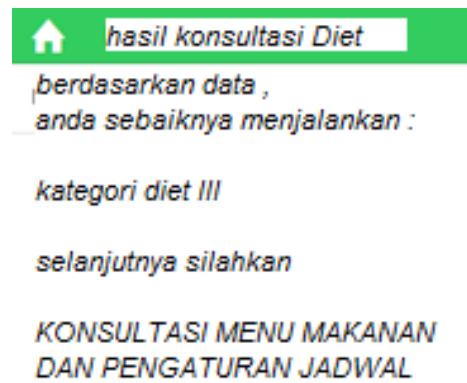

****SELAMAT*k:

Copyright $\odot$ Your Need 2016

Gambar 12. Implementasi halamam "Kategori Diet”

Informasi nilai gizi seperti pada Gambar 13 berisi tentang kandungan gizi dalam suatu bahan makanann, yang diinputkan oleh admin, diantaranya menurut [8], Kandungan Nutrisi per 100 gram bahan makanan diantaranya:

1. Apel, mengandung Karbohidrat 15.25 gr (Gram)

2. Pepaya, mengandung Karbohidrat 9.81 gr (Gram)

3. Susu Kacang, mengandung Lemak 1.91 gr (Gram)

4. Kembang Kol, mengandung Protein 1.98 gr(Gram)

5. Terong, mengandung Protein $1.02 \mathrm{gr}$ (Gram)

6. Sawi, mengandung Serat $4.76 \mathrm{gr}$ (Gram)

7. Kangkung, mengandung Serat 2 gr (Gram)

8. Tomat, mengandung Serat 0.9 gr (Gram)

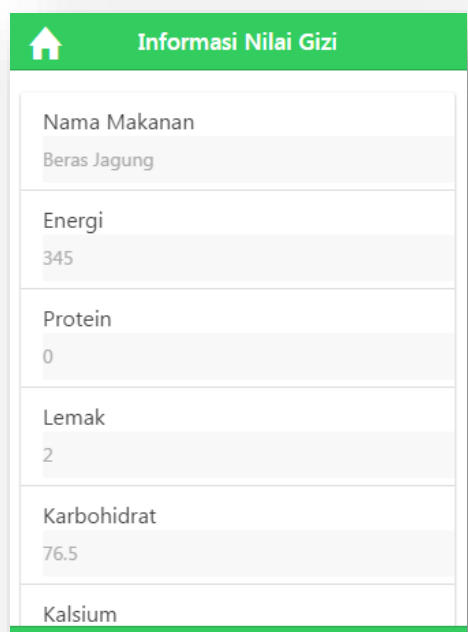

Copyright @ Your Need 2016

Gambar 13. Implemetasi Halaman info bahan makanan 
Selanjutnya dari database kandungan gizi pada bahan makanan ini akan dihasilkan informasi rancangan bahan makanan yang direkomendasikan untuk users seperti terlihat pada gambar 13 dan gambar 14.

\section{KESIMPULAN}

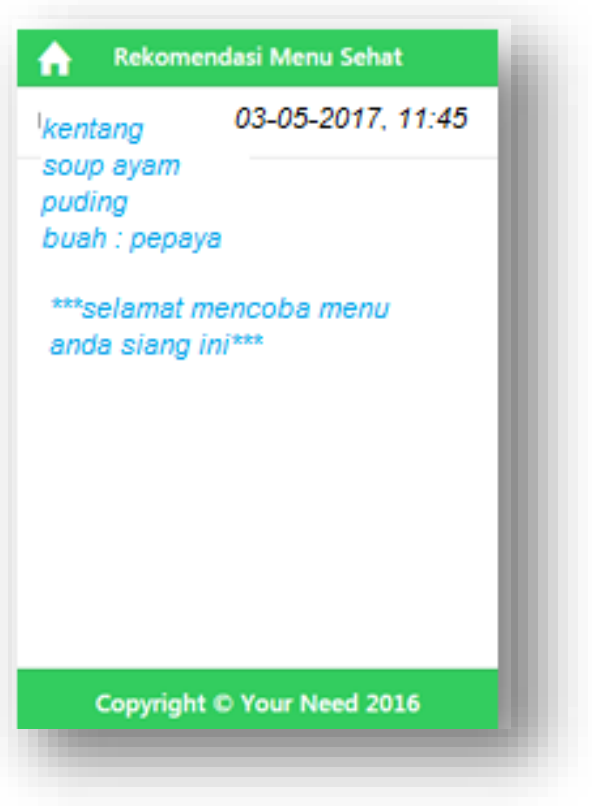

Gambar 14. Detail Rekomendasi Menu Sehat.

Berdasarkan perrancangan system pendukung keputusan dapat disimpulkan bahwa sistem ini dirancang dengan meminta masukan berupa data berat badan, tinggi badan, jenis kelamin, umur, aktifitas fisik sehingga nantinya dengan metode naïve bayes system ini akan memberikan output category diet dan menu makanan sehat yang direkomendasikan buat selanjutnya dijalani sebagai proses diet.

\section{DAFTAR PUSTAKA}

[1] Hawks dkk. 2008. "Classroom approach for managing dietary restraint, negative eating styles, and body image concerns among college women". Journal of American college health,56, 359366. 10

[2]. Kim, M, \& Sharron J Lennon. 2006. "Analysis of diet advertisements: A cross national comparasion of Korean and U.S. woman's magazines". Clothing and textiles research journal, 24, 345-363.

[3] Alter, S. (2008). The Work System Method: Connecting People, Processes, and IT for Business Results. Works System Press, CA).

[4] Raymond McLeod, Jr. dan George P. Schell. (2007). Sistem Informasi Manajemen. Edisi kesembilan. Penerbit Indeks. Jakarta.

[5]. Perwira R. 2012 . 'Sistem untuk konsultasi menu diet bagi Penderita diabetes mellitus berbasis aturan”. Jurnal Teknologi, Volume 5 Nomor 2, Desember 2012,104-113

[6] Astri Herdiyanti dan Utami Dewi Widianti. 2013. "Pembangunan Sistem Pendukung Keputusan Rekrutmen Pegawai Baru Di PT. ABC". Jurnal Ilmiah Komputer dan Informatika (KOMPUTA) 49 Vol. 2, No. 2, Oktober 2013, ISSN : 2089-9033

[7]. Almatsier.(2007). Penuntun Diet Edisi Baru, PT.Gramedia Pustaka. Jakarta.

[8] Arief Jananto. 2013. "Algoritma Naïve Bayes Untuk Mencari Perkiraan Waktu Studi Mahasiswa,” Jurnal Tekhnologi Informasi DINAMIK, vol 18, no.1, Januari 2013 